\title{
Beef cattle behavior in integrated crop-livestock systems
}

\author{
Daniela Maria Martin ${ }^{1 *}$ (D) Renata Franciéli Moraes ${ }^{1}$ Maria Christine Rizzon Cintra ${ }^{2}$ (D) \\ Claudete Reisdorfer Lang ${ }^{1}$ (i) Alda Lúcia Gomes Monteiro ${ }^{3}$ (i) \\ Leandro Bittencourt de Oliveira ${ }^{1}$ (D) Anibal de Moraes $^{1}$ (i)
}

${ }^{1}$ Departamento de Fitotecnia e Fitossanitarismo, Universidade Federal do Paraná (UFPR), 80035-050, Curitiba, PR, Brasil. E-mail: danielammartin@gmail.com. ${ }^{*}$ Corresponding author.

${ }^{2}$ Departamento de Medicina Veterinária, Universidade Federal do Paraná (UFPR), Curitiba, PR, Brasil.

${ }^{3}$ Departamento de Zootecnia, Universidade Federal do Paraná (UFPR), Curitiba, PR, Brasil.

ABSTRACT: Temperament often depends on the animals' reaction to people, social and environmental conditions. However, little is known about the influence of changes in the pasture environment on cattle temperament. Thus, this study was designed to evaluate if an animals' temperament changes in response to being kept in a silvopastoral system. This study evaluated the effect of the tree components in a pasture environment on the temperament of any grazing cattle in integrated crop-livestock systems. A total of thirty-two Angus steers were allocated to either a livestock (L) or livestock-forest (LF) system and observed from December 2019 to February 2020. Each animal was evaluated for their reactivity score, flight speed, and number of vocalizations. The statistical model established that the animals were random effects and that the treatments and periods were fixed effects using the MIXED procedure, and the means were compared using LSMeans. The flight speed and number of vocalizations were similar in both production systems, while the reactivity score was lower for animals kept in the LF system when compared to those in the L system. This suggested that the LF system interferes positively with the animal's temperament in relation to the L production system. However, additional research is needed to understand the influence of the production system on animal temperament. Key words: temperament, reactivity, animal welfare, silvopastoral.

Comportamento de novilhos de corte em sistemas integrados de produção agropecuária

RESUMO: As divergências no temperamento dependem da reação dos animais às pessoas e à diferentes situações sociais e ambientais. Contudo, pouco se sabe acerca da influência de alterações no ambiente pastoril sobre o temperamento dos bovinos. Com isso, a hipótese de trabalho é de que o temperamento dos animais pode ser alterado se mantidos em sistemas pastoris arborizados. Para tanto, objetivou-se avaliar o efeito do componente arbóreo em ambiente pastoril sobre o temperamento de bovinos em pastejo em sistemas integrados de produção agropecuária. Foram avaliados 32 novilhos da raça Angus alocados em dois sistemas pecuária (PEC) e pecuária-floresta (PF) durante o periodo de dezembro de 2019 a fevereiro de 2020, no qual foi mensurado: o escore de reatividade dos animais; a velocidade de fuga e o número de vocalizações. O modelo estatístico utilizado considerou como efeito fixo de tratamentos e períodos e efeitos aleatórios dos animais, utilizando o procedimento MIXED, as médias foram comparadas pelo recurso lsmeans. A velocidade de saida e número de vocalizações foram similares entre os sistemas de produção. O escore de reatividade foi menor para os animais mantidos no sistema PF quando comparados aos do tratamento PEC. O sistema PF interfere positivamente no temperamento animal em relação ao sistema de produção PEC, observado pelo menor escore de reatividade nos animais mantidos neste sistema. Contudo, o estudo sobre a influência da integração de sistemas sobre o temperamento animal exige mais pesquisas para revelar o potencial deste modelo de produção sobre o comportamento animal.

Palavras-chave: temperamento, reatividade, bem-estar animal, silvipastoril.

\section{INTRODUCTION}

The domestication of animals has highlighted the changes in their behavioral patterns in response to the presence of man, and the terms "tame", "docile" and "wild" began to be used to express the fear response within livestock herds in the early 1950s (SCOTT \& FREDERICSON, 1951).
The reaction of the animals when faced with an uncomfortable or threatening situation, whether of environmental origin, social dispute, or handling, triggers emotional responses manifested by behavioral changes which may vary in individual animals and herds (GRANDIN, 2000; PARHAM et al., 2019). The animal's response to these stressful situations and their expression of fear behavior 
is defined as their temperament (FORDYCE \& BURROW, 1992).

Wild cattle often exhibit aggressive or attacking behaviors increasing the risk of injury to the animals and workers, and the maintenance costs of the facilities, compromising the efficiency of routine operations (CARDOSO, 2016). The economic value of beef cattle temperament can be seen in the animals' weight gain, carcass quality, and the meat organoleptic characteristics. Some authors reported that animals with poor temperaments gain less weight (BEHRENDS et al., 2009; DEL CAMPO et al., 2010; SEBASTIAN et al., 2011). In general, the carcass of animals with poor temperaments has a higher incidence of bruises and increased $\mathrm{pH}$ values (above 5.8 ), resulting in a reduction in the organoleptic and sensory quality of the meat (FORDYCE et al., 1988; BURROW \& DILLON, 1997; CAFE et al., 2011; FELL et al., 1999; KING et al., 2006).

However, TURNER et al. (2011) stated that frequently handled Bos taurus of different temperaments showed no differences in performance, thus these results must be carefully extrapolated due to the intrinsic differences in the existing production systems. Animals kept in confinement may present with a more docile temperament compared to those kept in pastures, since constant contact with people in confined systems allowed confined animals to acclimate to their presence and associate it with greater food supply, reducing their fear response to humans; and consequently, making the animals more docile (JAGO et al., 1999; PETHERICK et al., 2009). Conversely, animals kept on pasture tend to have a more aggressive temperament as they have less contact with people (PETHERICK et al., 2009) and remain in an environment with more sources of stress (SCHULTE et al., 2018).

Although, the pasture is the most favorable environment for cattle allowing them to express more natural behaviors (FRASER et al., 2013), some characteristics of these systems cause stress to the animals, such as the absence of shade for protection against incident solar radiation, higher risk of contamination by parasites, absence of scratching devices, greater exposure to predators, and more competition for environmental resources. Some researchers report that animals kept on pasture present with more lesions, lameness, swelling and dirt accumulation in the hind limbs, hair loss, parasite infection, and thermal and nutritional stress, (BENNEMA et al., 2011; VANCE et al., 2012; VANDERSTICHEL et al., 2012; BUROW et al., 2013; VRIES et al., 2015; GIRO et al., 2019) reducing their comfort in the pasture environment and accentuating aggressive temperament.

Evaluations of confined steers temperament and its effect on their performance and $\mathrm{CH}_{4}$ emission have shown that the presence of steers with poor temperaments increases competition for food, resulting in disparities in the food consumption and performance of the herd (LLONCH et al. 2018). COOKE (2014) highlighted the impact of animal temperament on productive, reproductive and health characteristics in beef cattle and note the importance of developing strategies to improve temperament and increase productive efficiency. Nevertheless, little is known about the influence of changes in the pasture environment on cattle temperament.

Environmental enrichment is a strategy designed to help animals cope with environmental stressors and satisfy their behavioral needs (MANDEL et al., 2016). Environmental enrichment is defined as increasing the complexity of the environment and thereby improving the biological functioning of the animals (NEWBERRY, 1995). Thus, this study analyzed the application of environmental enrichment by observing the effects of adding a tree component to the pasture environment and assessing changes in the temperament of pasture grazed beef cattle. Therefore, this study evaluated the effect of livestock-forest and livestock production systems on the temperament of grazing cattle in integrated crop-livestock systems. The animals' reactivity score, flight speed from the cattle chute, and number of vocalizations in the cattle chute were measured.

\section{MATERIALS AND METHODS}

This study was conducted at the Experimental Farm at the Federal University of Paraná (UFPR), following the experimental protocol determined by the Center for Technological Innovation in Agriculture (DOMINSCHEK et al., 2018). The integrated production systems studied in this area include crop, livestock, forest, crop-livestock, cropforest, livestock-forest, and crop-livestock-forest. For this study, animals belonging to the livestock (L) and livestock-forest (LF) systems were evaluated between December 2019 and February 2020.

\section{Experimental conditions}

During the evaluation period, the temperature and the relative humidity of the air were measured daily in both systems (L and LF), using $\mathrm{HOBO}^{\circledR} \mathrm{RX} 3000$ meteorological stations, installed in situ (Table 1). A total of 32 Angus steers with a mean 
age of 18 months were evaluated, with 16 animals in each system. Table 1 summarizes the changes in the observed variables including weight, body condition score (BCS), which was determined using the Lowman et al. (1976) method, and mean daily gain consumption (ADG) of the herd over the evaluation period. The animals were kept in a continuous grazing system with variable load, according to the put-and-take technique (MOTT \& LUCAS, 1952) with a $24 \mathrm{~cm}$ sward target. The pasture primarily populated by Aries grass [Megathyrsus (e.g., Panicum maximum)] with the presence of spontaneous plants like Hemartria (Hemarthria altissima), Papuã grass [Urochloa (e.g., Brachiaria) plantaginea], and African stargrass (Cynodon plectostachyus). Table 1 shows the forage heights and frequencies of the animals over the course of the experiment. The animals had access to clean water and mineralized salt ad libitum. In the LF system, the tree component consisted of Eucalyptus benthamii, planted in 2013 using a $14 \mathrm{~m} \times 2 \mathrm{~m}$ spatial arrangement. During the period of this experiment the density of the tree component in the LF system was 130 plants per hectare with $44 \%$ tree shading.
The NITA protocol requires the application of rational handling of grazing cattle and this was applied in all production systems. The objective of this kind of handling is to keep people and animals safe, reduce cattle stress and injuries, and indirectly, increase production. The health management of endo and ectoparasites was selectively conducted, and medication was used only when animals reached a prescribed infestation limit as described by MOLENTO (2004).

\section{Variable measurements}

All evaluations were conducted during the summer (December 2019 to February 2020), with three data collections performed every 28 days, the first on December 19, 2019. The animal's temperament was assessed using reactivity score (RS), the exit time of the animal from the cattle chute to calculate flight seep, and the number of vocalizations of the animal in the cattle chute. The same observer made all assessments.

The RS variable was evaluated using the cattle in the chute, using an adaptation of the HEARNSHAW \& MORRIS (1984) method. These

Table 1 - Microclimate, animal and sward characterization in livestock (L) and livestock-forest (LF) production systems in the three evaluation periods.

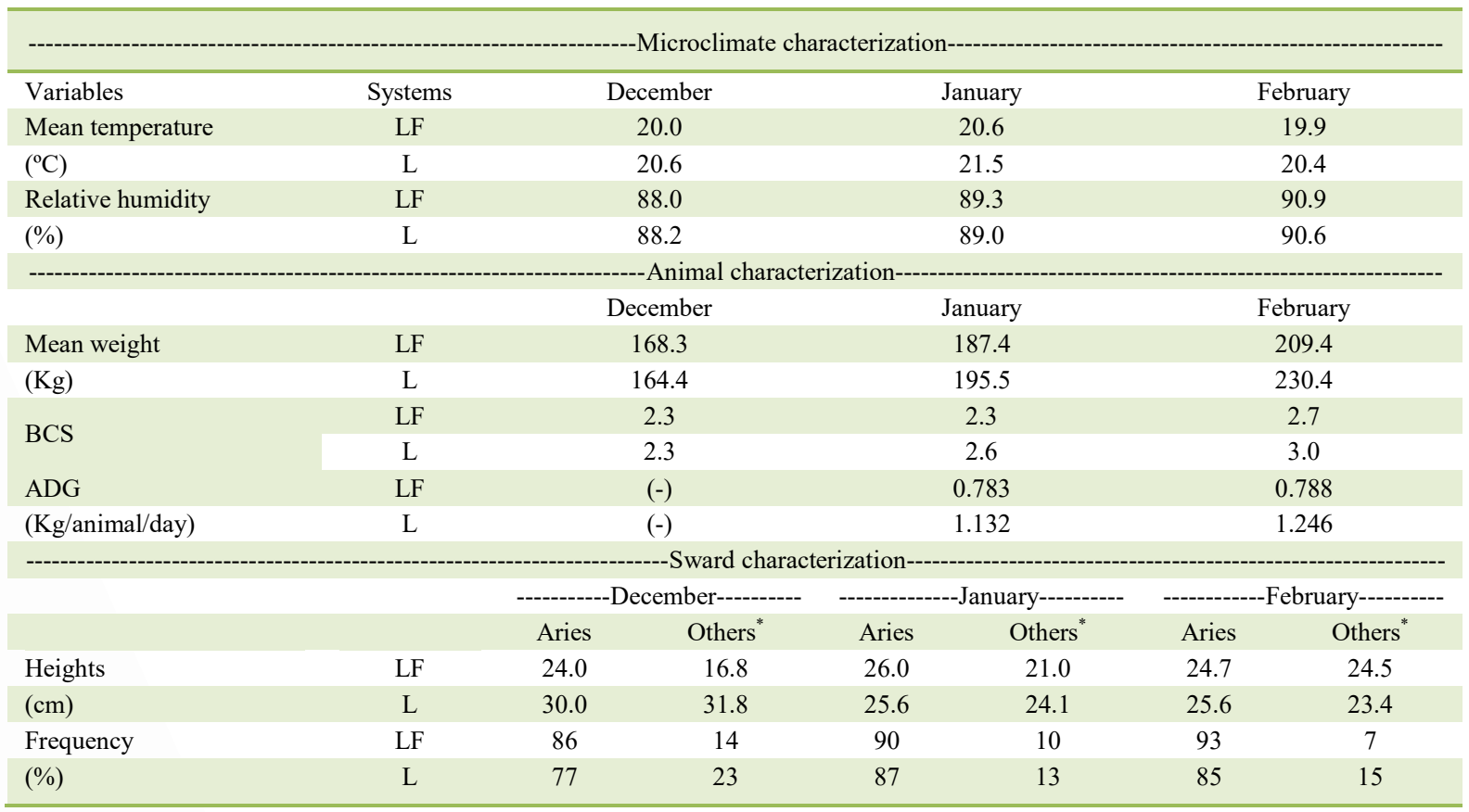

*Species set: Hemartria (Hemarthria altissima), Papuã grass [Urochloa (e.g., Brachiaria) plantaginea], and African stargrass (Cynodon plectostachyus). 
observations considered the general state of the animal including movement of the limbs, head and tail, and signs of stress. The animal enters the cattle chute and the gates are closed, five seconds later the corresponding score is assigned as follows: 1. Animal shows no resistance, remains with ears, head, and tail relaxed; 2. Animal shows little movement in the limbs and keeps head and ears erect; 3 . Animal shows frequent and non-vigorous movements in the limbs, head, ear, and tail; 4. Animal shows great resistance, vigorously moves the limbs, head and tail, breathing is audible, the animal can jump and fall; 5. Animal paralyzed, with muscle tremor.

The flight speed was calculated by the time it took the animal to leave the cattle chute, from the moment the gates were opened until reaching the corral corridor (known distance), according to the methodology from BURROW et al. (1988). The number of vocalizations was obtained by counting the number of vocalizations made by each animal between its entry into the cattle chute and its release.

\section{Data analysis}

The experimental design was completely randomized, using two systems as treatments ( $\mathrm{L}$ and LF) and completing sixteen repetitions for each treatment. The experiment was conducted over three evaluation periods, which were treated as repeated measures over time. The study used a mixed effect model with the fixed effects being the treatment and evaluation periods and the random effects being the animal behavior. All evaluations were completed using the MIXED procedure. The Shapiro-Wilk test was used to evaluate data normality for each variable and the Bartlett test was used to verify homogeneity of variances and independence of errors. Both vocalization and flight speed were normal after being transformed into their log values. Differences between treatments were evaluated using LSMeans. Structure selection tests were performed using the lowest value of the Akaike Information Criterion (AIC) to determine the model that best represents the data. The interaction between the treatments and evaluation periods was split when significant at $5 \%$ probability. The RS did not present with normal behavior even after transformation meaning that these variables were evaluated using an analysis of variance (ANOVA) for non-parametric data using the Kruskal-Wallis test. Statistical evaluations were completed using SAS 9.4 statistical software and the maximum significance level was $5 \%$.

\section{RESULTS AND DISCUSSION}

The animals' reactivity score (RS) was $24.95 \%$ higher $(\mathrm{P}=0.0147)$ in the $\mathrm{L}$ system $(4.85 \pm$ $2.37)$ when compared to the LF system $(3.64 \pm 2.38)$. The mean RS was $4.25 \pm 2.40$, and similar between the evaluation periods $(\mathrm{P}=0.0842)$.

The animals in the $\mathrm{L}$ system showed a higher reactivity score in the cattle chute, with $35.4 \%$ of the animals showing an RS in the more reactive classes 3, 4 and 5, whereas animals in the LF system had significantly fewer animals in these same classes (12.5\%; Figure 1). In addition, there were no records of animals with a 5-point score in the LF system. In both systems, the animals underwent the same handling and routine, thus, the difference in the RS results are attributed to the environmental conditions in each productive system. Silvopastoral was designed to better accommodate grazing animals' thermal comfort (NARDONE et al., 2010; BROOM et al., 2013; PEZZOPANE et al., 2019), but there is still no research that reports if the tree component is capable of changing the animals' temperament. Although, the reactivity in the $\mathrm{L}$ system was higher than that of LF, this was not reflected in the ADG. The L system had a mean ADG of $1.189 \mathrm{~kg}$ of LW.animal ${ }^{-1}$. day ${ }^{-1}$ which was higher than that of the LF system which had a mean ADG of $0.785 \mathrm{~kg}$ of LW.animal ${ }^{-1}$.day ${ }^{-1}$ (Table 1).

There was no interaction between these systems and the assessment periods for number of vocalizations $(\mathrm{P}=0.8281)$ and flight speed $(\mathrm{P}=0.8174)$ (Table 2). There were no statistically significant difference in either value between these systems $(\mathrm{P}=0.8091)$ or evaluation periods $(\mathrm{P}=0.5231)$ for the number of vocalizations or flight speed, $\mathrm{P}=0.7024$ and $\mathrm{P}=0.2609$, respectively. However, it is worth noting that the mean number of vocalizations $(0.48)$ and the mean flight speed $\left(0.60 \mathrm{~ms}^{-1}\right)$ were both relatively low indicating the low reactivity of these animals.

The low flight speed (Table 2) and the high productive performance of the animals (Table 1) evaluated in this study corroborated the results reported by PETHERICK et al. (2002, 2003). The fact that significant differences between the systems for flight speed were not identified is justified by the fact that this variable is an innate aspect of animal temperament (PETHERICK et al., 2002, 2009) being moderately heritable (BURROW \& CORBET, 2000). This study did not use habituation and conditioning protocols with positive reinforcement as these may reduce cattle flight speed. Increased habituation to handling may have revealed more statistically significant 


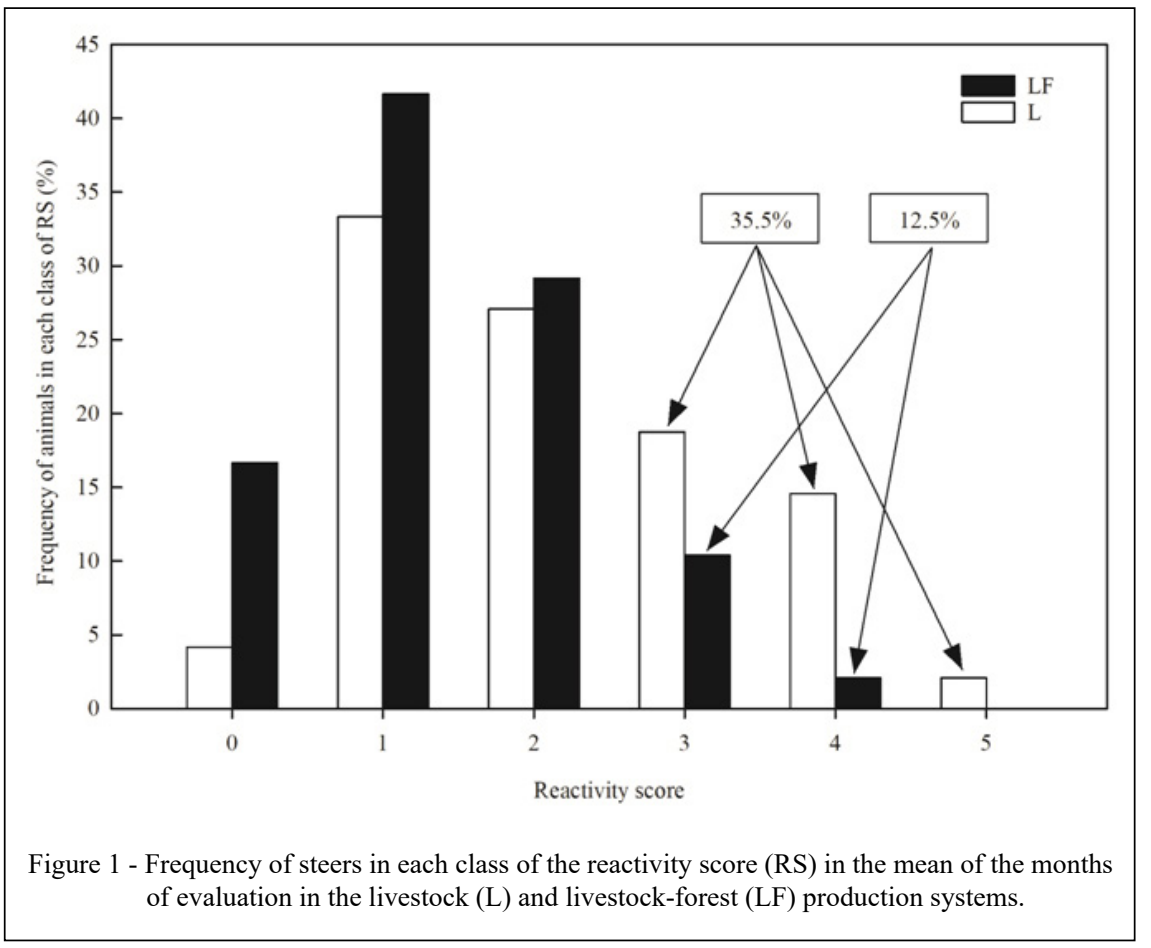

changes in behavior, as observed by PARHAM et al. (2019). When evaluating the steers temperament over three consecutive years, these authors concluded that they became more docile with repeated rational handling, as indicated by a reduction in flight speed and reactivity scores over time (PARHAM et al., 2019).

This study results showed that the inclusion of trees in the pasture environment favors acclimatization, a process that arises from a combination of habituation, associative learning, and physiological adaptation (MONK et al., 2018). The animals feel more acclimatized and comfortable in the LF system, reducing their fearful behavior as demonstrated by their more docile temperament.

This study explored the influence of the tree component on animal temperament. However, there were some limitations which should be addressed

Table 2 - Means and standard deviation for number of vocalizations and flight speed ( $\left.\mathrm{m} \mathrm{s}^{-1}\right)$ for the systems (L and LF) and evaluation periods $(1,2$ and 3$)$.

\begin{tabular}{|c|c|c|c|c|c|c|c|}
\hline \multirow[t]{2}{*}{ Systems } & \multicolumn{3}{|c|}{-----------------------------Evaluation period-------------------------- } & \multirow[t]{2}{*}{ Mean \pm SD } & \multirow[t]{2}{*}{$\mathrm{P}^{*}$} & \multirow[t]{2}{*}{$\mathrm{P}^{* *}$} & \multirow[t]{2}{*}{$\mathrm{P}^{* * *}$} \\
\hline & 1 & 2 & 3 & & & & \\
\hline \multicolumn{8}{|c|}{ 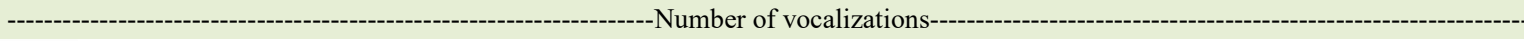 } \\
\hline $\mathrm{L}$ & $0.81 \pm 2.99$ & $0.25 \pm 1.00$ & $0.06 \pm 0.25$ & $0.37 \pm 1.41$ & 0.8091 & 0.5231 & 0.8281 \\
\hline LF & $1.31 \pm 4.99$ & $0.44 \pm 0.89$ & $0.06 \pm 0.25$ & $0.60 \pm 2.04$ & & & \\
\hline Mean \pm SD & $1.06 \pm 3.99$ & $0.34 \pm 0.94$ & $0.06 \pm 0.25$ & & & & \\
\hline \multicolumn{8}{|c|}{---1 } \\
\hline L & $0.74 \pm 0.45$ & $0.66 \pm 0.35$ & $0.59 \pm 0.30$ & $0.66 \pm 0.37$ & 0.7024 & 0.2609 & 0.8174 \\
\hline LF & $0.62 \pm 0.16$ & $0.61 \pm 0.26$ & $0.59 \pm 0.25$ & $0.60 \pm 0.22$ & & & \\
\hline Mean \pm SD & $0.68 \pm 0.30$ & $0.64 \pm 0.30$ & $0.59 \pm 0.28$ & & & & \\
\hline
\end{tabular}

"Probability between systems; ${ }^{* *}$ Probability between evaluation periods; ${ }^{* * *}$ Probability for interaction between systems and evaluation periods; $\mathrm{SD}=$ standard deviation; lowercase letters in the columns differ from each other by the Tukey test $(\mathrm{P}<0.05)$ 
to help better explore this relationship. The evaluation period was short, making it impossible to observe these behavior based variables over time. In addition, the use of animals in the rearing phase did not allow assessments of the quality of the carcass, which could better demonstrate changes in the animals' temperament in the different systems. Thus, more research must be conducted to better understand the effect of this integration model on animal temperament and well-being.

\section{CONCLUSION}

The livestock-forest or silvopastoral system has a positive effect on animal temperament when compared to the livestock production system, as this system reduces the animals' reactivity score. More research should be conducted to explore the influence of the tree component on the temperament of grazing cattle.

\section{ACKNOWLEDGMENTS}

The authors thank the Coordenação de Aperfeiçoamento de Pessoal de Nível Superior (CAPES), Brazil, and the Conselho Nacional de Desenvolvimento Científico e Tecnológico $(\mathrm{CNPq})$, Brazil, for financing this project and the NITA experimental protocol.

\section{BIOETHICS AND BIOSAFETY COMMITTEE APPROVAL}

This study was approved by the Ethics Committee on the use of animals from the Agricultural Sciences Sector of the Universidade Federal do Paraná - protocol number 075_2019.

\section{DECLARATION OF CONFLICT OF INTEREST}

The authors have no conflicts of interest to declare. There are no financial, commercial, political, academic, or personal conflicts. Funders had no influence on the design of the project, data collection, analysis, and interpretation or the writing of the manuscript and the decision to publish the results.

\section{AUTHORS' CONTRIBUTION} this manuscript.

All authors contributed equally to the preparation of

\section{REFERENCES}

BEHRENDS, S. M. et al. Relationship of temperament, growth, carcass characteristics and tenderness in beef steers. Meat Science, v.81, n.3. p.433-438, 2009. Available from: $<$ https://doi. org/10.1016/j.meatsci.2008.09.003>. Accessed: Sep. 13, 2020. doi: 10.1016/j.meatsci.2008.09.003.
BENNEMA, S. C. et al. Relative importance of management, meteorological and environmental factors in the spatial distribution of Fasciola hepatica in dairy cattle in a temperate climate zone. International Journal for Parasitology, v.41, n.2, p.225-233, 2011. Available from: <https://doi.org/10.1016/j. ijpara.2010.09.003>. Accessed: May, 25, 2020. doi: 10.1016/j. ijpara.2010.09.003.

BROOM, D. M. et al. Sustainable, efficient livestock production with high biodiversity and good welfare for animals. Proceedings of the Royal Society B: Biological Sciences, v.280 n.1771, p.2013-2025, 2013. Available from: <https://doi.org/10.1098/ rspb.2013.2025>. Accessed: Jul. 12, 2020. doi: 10.1098/ rspb.2013.2025.

BURROW, H. M.; CORBET, N. J. Genetic and environmental factors affecting temperament of zebu and zebu-derived beef cattle grazed at pasture in the tropics. Australian Journal of Agricultural Research, v.51, n.1, p.155-162, 2000. Available from: <https://agris.fao.org/agris-search/search. do? recordID=US201302937890 >. Accessed: Jul. 12, 2020. doi: 10.1071/AR99053.

BURROW, H. M.; DILLON, R. D. Relationships between temperament and growth in a feedlot and commercial carcass traits of Bos indicus crossbreds. Australian Journal of Experimental Agriculture, v.37, n.4 p.407-411, 1997.Available from: <https:// www.publish.csiro.au/an/EA96148>. Accessed: Sep. 13, 2020. doi: 10.1071/EA96148.

BURROW, H. M. et al. A new technique for measuring temperament in cattle. In: Proceedings of the Australian Society of Animal Production. v.17 p.154-157, 1988. Available from: $<$ http://hdl.handle.net/102.100.100/263651?index=1>. Accessed: Sep. 13, 2020

CAFE, L. M. et al.. Cattle temperament: Persistence of assessments and associations with productivity, efficiency, carcass and meat quality traits. Journal of Animal Science, v.89, n.5, p.1452-1465, 2011. Available from: <https://doi.org/10.2527/jas.2010-3304>. Accessed: Sep. 13, 2020. doi: 10.2527/jas.2010-3304.

CARDOSO, C. S. et al. Imagining the ideal dairy farm. American Dairy Science Association, v.99, n.2, p.1663-1671, 2016. Available from: <https://doi.org/10.3168/jds.2015-9925>. Accessed: May, 25, 2020. doi: 10.3168/jds.2015-9925.

COOKE, R. F. Temperament and acclimation to human handling influence growth, health, and reproductive responses in Bos taurus and $B$. indicus cattle. Journal of Animal Science, v.92, p.53255333, 2014. Available from: <https://doi.org/10.2527/jas.20148017>. Accessed: Apr. 14, 2021. doi: 10.2527/jas.2014-8017.

DEL CAMPO, M. et al. Finishing diet, temperamento and lairage time effects on carcass and meat quality traits in steers. Meat Science, v.86, n.4, p.908-914, 2010. Available from: <https://doi. org/10.1016/j.meatsci.2010.07.014>. Accessed: Sep. 13, 2020. doi: 10.1016/j.meatsci.2010.07.014.

DOMINSCHEK, R. et al. Sistemas Integrados de Produção Agropecuária na Promoção da Intensificação Sustentável. Curitiba: Universidade Federal do Paraná, 2018.79p. (Boletim técnico, 1).

FELL L.R. et al. Associations between temperament, performance and immune function in cattle entering entering a commercial 
feedlot. Australian Journal of Experimental Agriculture, v.39, n.7, p.795- 802, 1999. Available from: <https://doi.org/10.1071/ EA99027>. Accessed: Sep. 13, 2020. doi: 10.1071/EA99027.

FORDYCE, G.; BURROW, H. Temperament of Bos indicus bulls and its influence on reproductive efficiency in the tropics. In: WORKSHOP BULL FERTILITY, 1992, Queensland, Australia. Proceedings... Queensland: Department of Primary Industries, 1992. p.35-37. Online. Available from: <http://hdl.handle.net/102 $.100 .100 / 246227$ ?index $=1>$. Accessed: Sep. 13, 2020 .

FORDYCE G. et al. Cattle temperaments in extensive beef herds in northern Queensland. 2. Effect of temperament on carcass and meat quality. Australian Journal of Experimental Agriculture, v.28, n. 6, p 689-693, 1988. Available from: <https://doi.org/10.1071/ EA9880689>. Accessed: Sept, 13, 2020. doi: 10.1071/EA9880689.

FRASER, D. et al. General Principles for the welfare of animals in production systems: The underlying science and its application. The Veterinary Journal, v.198, n.1, p.19-27, 2013. Available from: <http://dx.doi.org/10.1016/j.tvj1.2013.06.028>. Accessed: Jun. 2, 2020. doi: 10.1016/j.tvj1.2013.06.028.

GIRO, A. et al. Behavior and body surface temperature of beef cattle in integrated crop-livestock systems with or without tree shading. Science of the Total Environment, v.684, p.587-596, 2019. Available from: $<$ https://doi.org/10.1016/j.scitotenv.2019.05.377>. Accessed: Jun. 20, 2020. doi: 10.1016/j.scitotenv.2019.05.377.

GRANDIN, T. Livestock handling and transport. Wallingford: Cabi Publishing, 2000. 3ed.

HEARNSHAW, H.; MORRIS, C.A. Genetic and environmental effects on temperamento score in beef cattle. Australian Journal of Agricultural Research, v.35, n.5, p.723-733, 1984. Available from: <https://doi.org/10.1017/S1751731111001169>. Accessed: Jun. 21, 2020. doi: 10.1017/S1751731111001169.

JAGO, J. G. et al. The influence of feeding and handling on the development of the human-animal interactions in young cattle. Applied Animal Behaviour Science, v.62, p.137-151, 1999. Available from: <https://doi.org/10.1016/S0168-1591(98)00219-6>. Accessed: Sep. 13, 2020. doi: 10.1016/S0168-1591(98)00219-6.

KING, D. A. et al. Influence of animal temperament and stress responsiveness on the carcass quality and beef tenderness of feedlot cattle. Meat Science, v.74, n.3, p.546-556, 2006. Available from: <https://doi.org/10.1016/j.meatsci.2006.05.004>. Accessed: Sep. 20, 2020. doi: 10.1016/j.meatsci.2006.05.004.

LLONCH, P. et al. Temperament and dominance relate to feeding behaviour and activity in beef cattle: implications for performance and methane emissions. Animal, v.12, n.12, p.2639-2648, 2018. Available from: <https://doi.org/10.1017/S1751731118000617>. Accessed: Apr. 14, 2021. doi: 10.1017/S1751731118000617.

LOWMAN, B.G.N. et al. Condition scoring of cattle. Edinburgh: The Edinburgh School of Agriculture, 1976. 5p.

MANDEL, R. et al. Invited review: Environmental enrichment of dairy cows and calves in indoor housing. Journal of Dairy Science, v.99, n.3, p.1695-1715, 2016. Available from: <https://doi.org/10.3168/ jds.2015-9875>. Accessed: Sep. 13, 2020. doi: 10.3168/jds.2015-9875.

MOLENTO, M. B. Helminth resistance in sheep and goats. Revista Brasileira de Parasitologia Veterinária, v.13, n.1, p.82-87, 2004. Available from: <https:/www.researchgate.net/ publication/284055595_Resistencia_de_helmintos_em_ovinos_e caprinos>. Accessed: Jul. 21, 2020.

MONK, J. E. et al. A novel protocol to assess acclimation rate in Bos taurus heifers during yard weaning. Animals, v.8, n.4, p.5165, 2018. Available from: <https://www.ncbi.nlm.nih.gov/pmc/ articles/PMC5946135/>. Accessed: Jul. 12, 2020. doi: 10.3390/ ani8040051.

MOTT, G. O.; LUCAS, H. L. The design, conduct and interpretation of grazing trials on cultivated and improved pastures. In International Grassland Congress, v.6, n.1952, p.13801395, 1952. Available from: <https://agrilife.org/spfcic/annualproceedings $/ 56$ th/the-conduct-of-grazing-trials-rationale $/>$. Accessed: Jun. 3, 2020.

NARDONE, A. et al. Effects of climate changes on animal production and sustainability of livestock systems. Livestock Science, v.130, n.1-3, p.57-69, 2010. Available from: $<$ https://doi. org/10.1016/j.livsci.2010.02.011>. Accessed: Jul. 12, 2020. doi: 10.1016/j.livsci.2010.02.011.

NEWBERRY, R. C. Environmental enrichment: Increasing the biological relevance of captive environments. Applied Animal Behaviour Science, v.44 p.229-243, 1995. Available from: <https://doi.org/10.1016/0168-1591(95)00616-Z>. Accessed: Sep. 20, 2020. doi: 10.1016/0168-1591(95)00616-Z.

PARHAM, J. T. et al. Temperamental cattle acclimate more substantially to repeated handling. Applied Animal Behaviour Science, v.212, p.36-43, 2019. Available from: <https://doi. org/10.1016/j.applanim.2019.01.001>. Accessed: Jun. 21, 2020. doi: 10.1016/j.applanim.2019.01.001.

PETHERICK, J. C. et al. Productivity, carcass and meat quality of lot-fed Bos indicus cross steers grouped according to temperament. Australian Journal Experimental Agriculture, v.42, p.389398, 2002. Available from: <https://www.publish.csiro.au/an/ EA01084>. Accessed: Jul. 5, 2020. doi: 10.1071/EA01084.

PETHERICK, J. C. et al. Performance of lot-fed Bos indicus steers exposed to aspects of a feedlot environment before lotfeeding. Australian Journal Experimental Agriculture, v.43, p.11811191, 2003. Available from: <https://www.publish.csiro.au/an/ EA02118>. Accessed: Jul. 5, 2020. doi: 10.1071/EA02118.

PETHERICK, J. C. et al. Quality of handling and holding yard environment, and beef cattle temperament: 1. Relationships with flight speed and fear of humans. Applied Animal Behaviour Science, v.120, n.1-2, p.18-27, 2009. Available from: $<$ https://doi. org/10.1016/j.applanim.2009.05.008>. Accessed: Jul. 5, 2020. doi: 10.1016/j.applanim.2009.05.008.

PEZZOPANE, J.R.M. et al. Animal thermal comfort indexes in silvopastoral systems with different tree arrangements. Journal of Thermal Biology, v. 79, p. 103-111, 2019. Available from: $<$ https://doi.org/10.1016/j.jtherbio.2018.12.015>. Accessed: Jul, 12, 2020. doi: 10.1016/j.jtherbio.2018.12.015.

SCHULTE, H. D. et al. Let the cows graze: An empirical investigation on the trade-off between efficiency and farm animal welfare in milk production. Land Use Policy, v.79, p.375-385, 2018. Available from: <https://doi.org/10.1016/j. landusepol.2018.07.005>. Accessed: Jul. 12, 2020. doi: 10.1016/j. landusepol.2018.07.005. 
SCOTT, J.; FREDERICSON E. The causes of fighting in mice and rats. Physiological Zoölogy, v.24, n.4, p.273-309, 1951. Available from: $<$ https://www.jstor.org/stable/30152137>. Accessed: Sep. 13, 2020.

SEBASTIAN, T. et al. Temperament in beef cattle: Methods of measurement and their relationship to production. Canadian Journal of Animal Science, v.91, n.4, p.557-565, 2011. Available from: <https://doi.org/10.4141/cjas2010-041>. Accessed: Sep. 20, 2020. doi: $10.4141 /$ cjas2010-041.

TURNER, S. P. et al. Associations between response to handling and growth and meat quality in frequently handled Bos taurus beef cattle. Journal of Animal Science, 89, n.2, p.4239-4248, 2011. Available from: <https://doi.org/10.2527/jas.2010-3790>. Accessed: Sep. 20, 2020. doi: 10.2527/jas.2010-3790.

VANCE, E. R. et al. Food intake, milk production, and tissue changes of Holstein-Friesian and Jersey x Holstein- Friesian dairy cows within a medium-input grazing system and a high-input total confinement system. Journal of Dairy Science, v.95, n.3, p.15271544, 2012. Available from: <https://doi.org/10.3168/jds.20114410>. Accessed: Jun. 3, 2020. doi: 10.3168/jds.2011-4410.

VANDERSTICHEL, R. et al. Effects of farm management practices and environmental factors on bulk tank milk antibodies against gastrointestinal nematodes in dairy farms across Canada. Preventive Veterinary Medicine, v.104, n.12, p.53-64, 2012. Available from: <https://doi.org/10.1016/j. prevetmed.2011.09.022>. Accessed: May, 5, 2020. doi: 10.1016/j. prevetmed.2011.09.022.

VRIES, M. et al. Housing and management factors associated with indicatorsof dairy cattle welfare. Preventive Veterinary Medicine, v.118, p.80-92, 2015. Available from: <http://dx.doi. org/10.1016/j.prevetmed.2014.11.016>. Accessed: Jun. 3, 2020. doi: 10.1016/j.prevetmed.2014.11.016. 